\title{
Rates of Quaternary deformation in the Ouarzazate Basin (Southern Atlas Front, Morocco)
}

\author{
Àlvar Pastor ${ }^{\star}$, Antonio Teixell, María Luisa Arboleya
}

Universitat Autònoma de Barcelona, Departament de Geologia, Bellaterra, Barcelona, Spain

\author{
Article history \\ Received December 22, 2010; accepted March 30, 2012. \\ Subject classification: \\ High Atlas, Morocco, Active tectonics, Quaternary, Slip rates, Seismic hazard.
}

\begin{abstract}
Recent studies have shown that the uplift of the Moroccan Atlas Mountains resulted from a combination of crustal shortening and mantle thermal processes in the interior of the African plate. Within this framework, to gain insight into the dynamics of these processes in recent times, we investigated the nature and rates of the Quaternary deformation in a case field area, namely, the northern Ouarzazate Basin, which contains the best dated records of fan and fluvial terrace deposits of the Atlas system. The area selected is in the southern orogenic front of the High Atlas, where thrusts and fault-related folds have affected a sequence of dated, stepped terraces to varying degrees. Based on cosmogenic nuclide surface exposure dating, we have calculated slow neotectonic deformation rates for the past $\sim 250 \mathrm{ky}$. We have measured the local rates of structural uplift, yielding $0.2 \mathrm{~mm} / \mathrm{y}$ in areas of the northern third of the Ouarzazate Basin. We have estimated slip rates at $0.09-0.15 \mathrm{~mm} / y$ for the most active fault within the basin. We also document that recent shortening rates $(\sim 0.1 \mathrm{~mm} / \mathrm{y}$ during the last $\sim 250 \mathrm{ky})$ almost double the average rates from the deformation onset ( $\sim 0.04 \mathrm{~mm} / y$ since the Middle Miocene). These results raise the point of the possible relations between such increases in the deformation rates and the erosional denudation of the Ouarzazate Basin since it became externally drained in the late Pliocene or early Quaternary times.
\end{abstract}

\section{Introduction}

Over the past 10 years, different studies have investigated the relationships between crustal shortening, mantle uplift, and surface processes, as the factors that control the topography of the Atlas Mountain system in Morocco [Teixell et al. 2003, Arboleya et al. 2004, Teixell et al. 2005, Missenard et al. 2006, Babault et al. 2008]. The structural style of the compressional deformation in the Moroccan High Atlas (Figure 1a) is mainly thick-skinned as a consequence of the Cenozoic inversion of extensional faults that were formed during a Mesozoic rifting episode [Mattauer et al. 1977, Laville and Piqué 1992, Frizon de Lamotte et al. 2000, Teixell et al. 2003]. Compressional deformation was active until Quaternary times [Meghraoui et al. 1998, Morel et al. 2000, Sébrier et al. 2006, Mridekh et al. 2009]. The major seismic activity of the
Atlas system follows the so-called Morocco Hot Line [Frizon de Lamotte et al. 2009], which crosses the system in a broadly SW-NE direction [Jacobshagen 1988, Ramdani 1998]. Although the tectonic style in the Atlas is mainly thick-skinned, the South Atlas Front (SAF) consists of a narrow fold-andthrust belt that involves Cretaceous to Neogene rock [Laville et al. 1977, Fraissinet et al. 1988]. A recent study constricted the timing of the thrusting during the Tertiary, based on tectonics-sedimentation relationships and magnetostratigraphic dating [Tesón and Teixell 2008, Tesón et al. 2010], deducing a continuous and slow shortening accommodation in the SAF, at an average rate of $0.3 \mathrm{~mm} / \mathrm{y}$ since the Oligocene.

The area analyzed in the present study is located in the widest part of the Ouarzazate Basin (Figure 1b), in its western half, covering approximately $50 \mathrm{~km}$ of the High Atlas foreland. Despite the discrepancies between studies, geological cross-sections of the SAF suggest a significant reduction in the accumulated shortening from $\mathrm{E}$ to $\mathrm{W}$ [Errarhaoui 1997, Tesón 2009]. Deformed terraces indicate that the activity of the SAF structures continued to recent times [Couvreur 1973, Sébrier et al. 2006], although seismicity in the area is not very different from other parts of the Atlas system that show less deformation and no signs of recent tectonics (Figure 1b).

The semi-arid climate of the southern High Atlas and the erosive dynamics of the Ouarzazate Basin allowed the development and preservation of extensive Quaternary terrace deposits, which cover much of the current surface of the basin. As these represent potentially datable surfaces, the Quaternary deposits that cross active faults and folds make ideal strain markers for the study of rates and kinematics of recent deformation [e.g., Avouac et al. 1993, Lavé and Avouac 2000, Thompson et al. 2002, Gold et al. 2006, Amos et al. 2007]. The tectonic deformation in the Ouarzazate Basin can be optimally characterized for both short (Quaternary markers) and long (bedrock) scales. Furthermore, both the tim- 


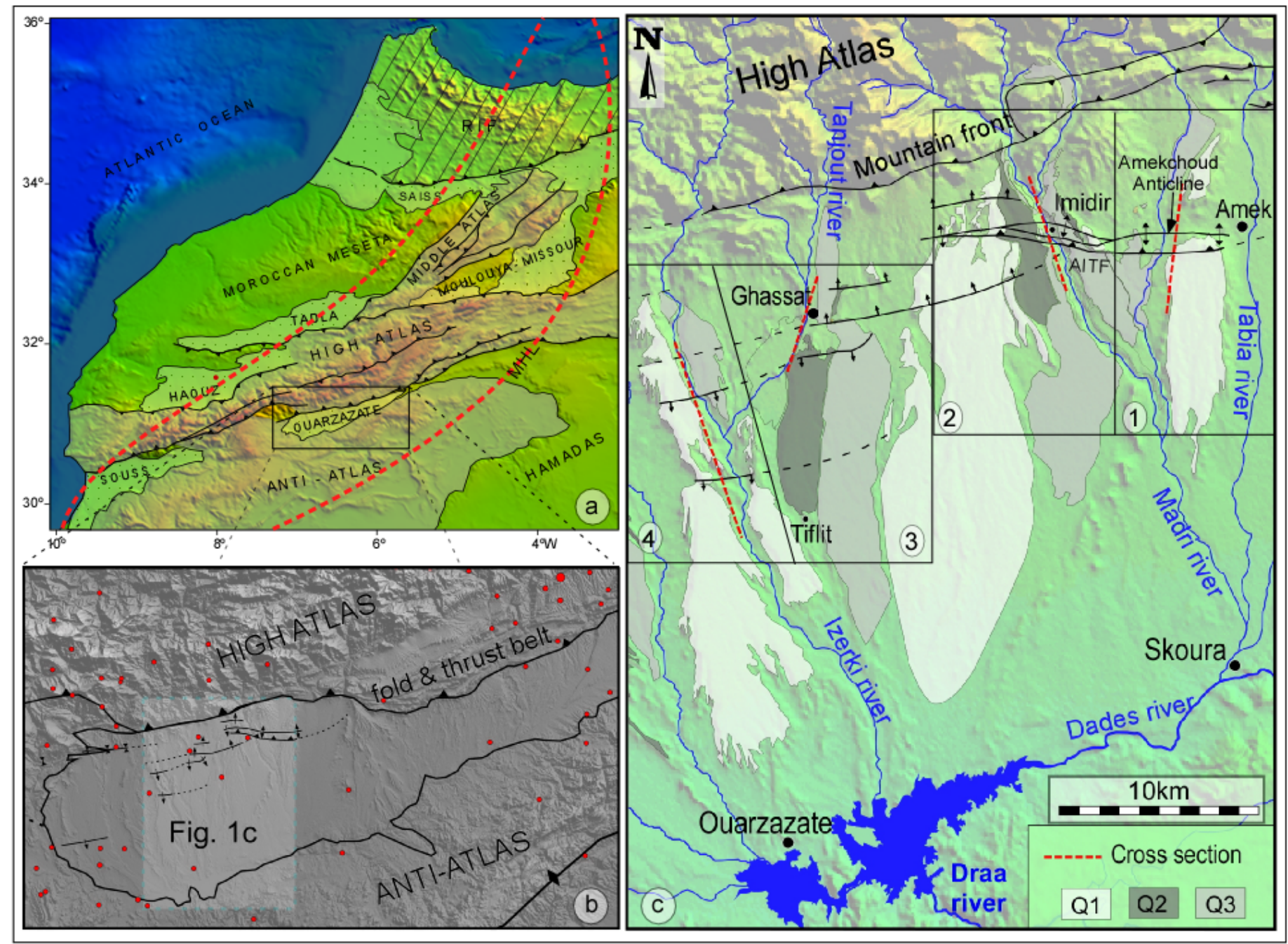

Figure 1. (a) Digital topography and tectonic sketch map of Morocco [after Teixell et al. 2009], showing the main morphotectonic units and the Moroccan Hot Line (MHL). Light dotted areas indicate Cenozoic basins. (b) Sketch map of the Ouarzazate Basin, indicating seismic events Mv $>3$ since 1964 (extracted from International Seismological Centre database). Background topography: Shuttle Radar Topographic Mission (SRTM90) composed image. The solid line encloses the extent of Tertiary and Quaternary deposits in the basin. (c) Map of the central part of the Ouarzazate Basin indicating the main Quaternary deposits (Q1 to Q3; see text for explanation) and structures. Boxes and numbers indicate the divisions of the study zone into the four areas (see text). Red dashed lines indicate the location of the geological cross-sections in Figure 3. Amek: locality of Amekchoud; AITF: Amekchoud-Imidir thrust fault.

ing/rates of sediment aggradation [magnetostratigraphic dating in Tesón et al. 2010] and degradation/incision rates [surface exposure dating in Arboleya et al. 2008] have also been roughly constrained. Profiles of deformed terraces extracted from digital elevation models (DEMs), field observations, seismic imagery, and surface exposure ages are combined to evaluate recent tectonic styles and to calculate the uplift and slip rates during the late Quaternary.

\section{Geographical and tectonic setting}

The Moroccan High Atlas (Figure 1a) is the most prominent topographic relief in North Africa, and is the Alpine intracontinental chain that was derived from the inversion of a transtensive rift of Triassic to Jurassic age [eg. Mattauer et al. 1977]. The total tectonic shortening across the High Atlas has been estimated at $15 \%$ to $25 \%$, increasing along the strike eastwards, while the topographic elevation generally decreases [Teixell et al. 2003]. This inverse correlation suggests that crustal thickening does not fully explain the observed topography, and suggests a mantle-sourced, thermal contribution to the uplift [Teixell et al. 2003], which is supported by geophysical [Seber et al. 1996, Ayarza et al. 2005, Teixell et al. 2005, Zeyen et al. 2005, Fullea et al. 2007] and geomorphic data [Babault et al. 2008].

Most of the orogenic shortening in the High Atlas is concentrated in the southern frontal thrust belt (the SAF), which affects Cretaceous to Neogene rock and overrides the Ouarzazate foreland basin [Laville et al. 1977, Fraissinet et al. 1988, Görler et al. 1988, Errarhaoui 1997]. The propagation sequence of this narrow fold-and-thrust belt is not simply a piggy-back one, but includes reactivation, and out-of-sequence and synchronous thrusting, that occurred essentially during the Neogene [Tesón and Teixell 2008]. Based on the restoration of a series of structural profiles, Tesón [2009] calculated the shortening for the SAF along different cross-sections from the eastern to the western boundaries of the 
study area, and documented a remarkable westward decrease in the shortening values.

The Ouarzazate Basin (Figure 1b) is located between the High Atlas frontal thrust belt and the domal uplift of the Anti-Atlas Mountains, which is composed of Precambrian to Paleozoic rock. The basin stands at an elevation of 1200 $\mathrm{m}$ a.s.l. to $1800 \mathrm{~m}$ a.s.l., and extends from $\mathrm{E}$ to $\mathrm{W}$ for more than $150 \mathrm{~km}$, and reaching a maximum width of $40 \mathrm{~km}$. It is filled by up to $1 \mathrm{~km}$ of Cenozoic (mainly Miocene) continental sediments, which on-lap the Anti-Atlas to the south and are overthrust by the High Atlas to the north. The Neogene to Quaternary history of the Ouarzazate Basin can be broadly divided into two periods. Its early record is dominated by net sedimentation, with Miocene fluvial and lacustrine sediments deposited within an internally drained basin [e.g., Görler et al. 1988, El Harfi et al. 2001]. In contrast, its later history is dominated by erosion, and began when the Draa River cut through the Anti-Atlas Mountains (Figure 1c) and the basin became externally drained via the Draa River canyon [Stäblein 1988, Arboleya et al. 2008, Guimerà et al. 2011]. The timing of the fluvial capture remains to be defined, although it probably occurred during the late Pliocene or early Pleistocene, as there is little evidence of large cut-fill sequences within the Tertiary infill of the basin [Arboleya et al. 2008]. A system of stepped alluvial fans and fluvial terraces formed during the late Pleistocene and Holocene, punctuating the incision.

\section{Stratigraphy}

\subsection{Tertiary bedrock}

The best profile for the Tertiary sedimentary succession is provided by the Amekchoud anticline (Figure 1c), a kmscale fold within the northern Ouarzazate Basin that exposes the oldest basin infill, which consists of a thick succession of red beds that were recently dated by magnetostratigraphy [Tesón et al. 2010]. The oldest infill is represented by the Hadida formation [Görler et al. 1988], which is composed of a 600-m-thick succession of red shale and sandstone, of Middle Eocene age [Tesón 2009]. After a sedimentary hiatus of ca. 23 My, the Ait Ouglif conglomerate [Fraissinet et al. 1988] were deposited unconformable locally in the core of the Ameckchoud anticline. Its age is Middle Miocene (Langhian-Serravalian) [Tesón et al. 2010]. The finer-grained overlying Ait Kandoula formation [Görler et al. 1988, El Harfi et al. 2001] (Middle to Upper Miocene) consists of a thick sequence (up to $800 \mathrm{~m}$ thick) of fluvial and lacustrine red shale, sandstone and conglomerate, with minor limestone, which overlies the Ait Ouglif conglomerate.

\subsection{Quaternary coarse-grained deposits}

Much of the current surface of the Ouarzazate Basin is covered with pediment and terrace sediments, often unconformable over Miocene beds and traditionally attributed to the Quaternary. These are preferentially located in the western, widest part of the Ouarzazate Basin, and they are related to the streams that drain from the High Atlas Mountains. Present-day streams are ephemeral and have irregular flow during the year, and they experience flash floods during heavy rainstorm events. Most of these have catchment areas smaller than $200 \mathrm{~km}^{2}$ and cross the basin in an approximately N-S direction to the southern edge, where they ultimately drain into the Dades-Draa River (Figure 1c).

Dating of the exposure surfaces (i.e., abandonment time of fans and terraces) for the Quaternary deposits was recently carried out by Arboleya et al. [2008] using cosmogenic nuclides. This was possible because many clasts are composed dominantly of rhyolite and other rock with high quartz contents, which allowed ${ }^{10} \mathrm{Be}$ geochronology. Most of the dated deposits are located in the Madri Valley, in the west-central part of the Ouarzazate Basin (Figure 1c), which contains the best records of stepped fluvial terraces in the entire basin. The surface of another extensive Quaternary fan-shaped deposit formed by the Tanjout River was dated near the locality of Ghassat (Figure 1c). On the basis of the results of cosmogenic nuclide dating, Arboleya et al. [2008] suggested that the creation and abandonment of the fan and terrace surfaces was controlled by climatic factors. These authors reported at least six well-defined surfaces, comprising alluvial fans, fluvial terraces and an active stream. The three higher surfaces show evidence of Quaternary deformation, having been numbered as Q1 (older) to Q3 (younger).

Q1 is the highest and oldest surface, with a favored age of $250 \mathrm{ka}$ to $278 \mathrm{ka}$, assuming a weathering rate of $1 \mathrm{~m} / \mathrm{My}$. This suggests that the terrace abandonment occurred during the late MIS-9 interglacial stage [Arboleya et al. 2008]. Q2 is a narrow and elongated fluvial terrace that is preserved on both sides of the current Madri River, and it can be traced for many kilometers along the valley. Assuming a weathering ratio of $1 \mathrm{~m} / \mathrm{My}$, the most favored age for this surface is 196 ka to $211 \mathrm{ka}$, which suggests terrace incision and abandonment during the post- or late-penultimate interglacial stage (MIS-7). Q3 was dated in the Madri Valley and at the Ghassat alluvial fan (Figure 1c). In both cases, it forms extensive surfaces that can be traced many kilometers along and across the rivers. Arboleya et al. [2008] calculated the most favored age for these surfaces as $96 \mathrm{ka}$ to $102 \mathrm{ka}$ (marine oxygen isotope stage $5 \mathrm{c}$ ).

It should be pointed out that the Quaternary surfaces of the Ouarzazate Basin are not always contiguous, and some deformed terrace remains have not been dated. Terrace mapping requires a correlation of dated and undated surfaces that is not always trivial. Avouac and Peltzer [1993] suggested that the ages of the climatically controlled surfaces are often similar across a region with similar climatic conditions. Thus, the abandonment of Quaternary depositional landforms should correspond to the general incision episodes 


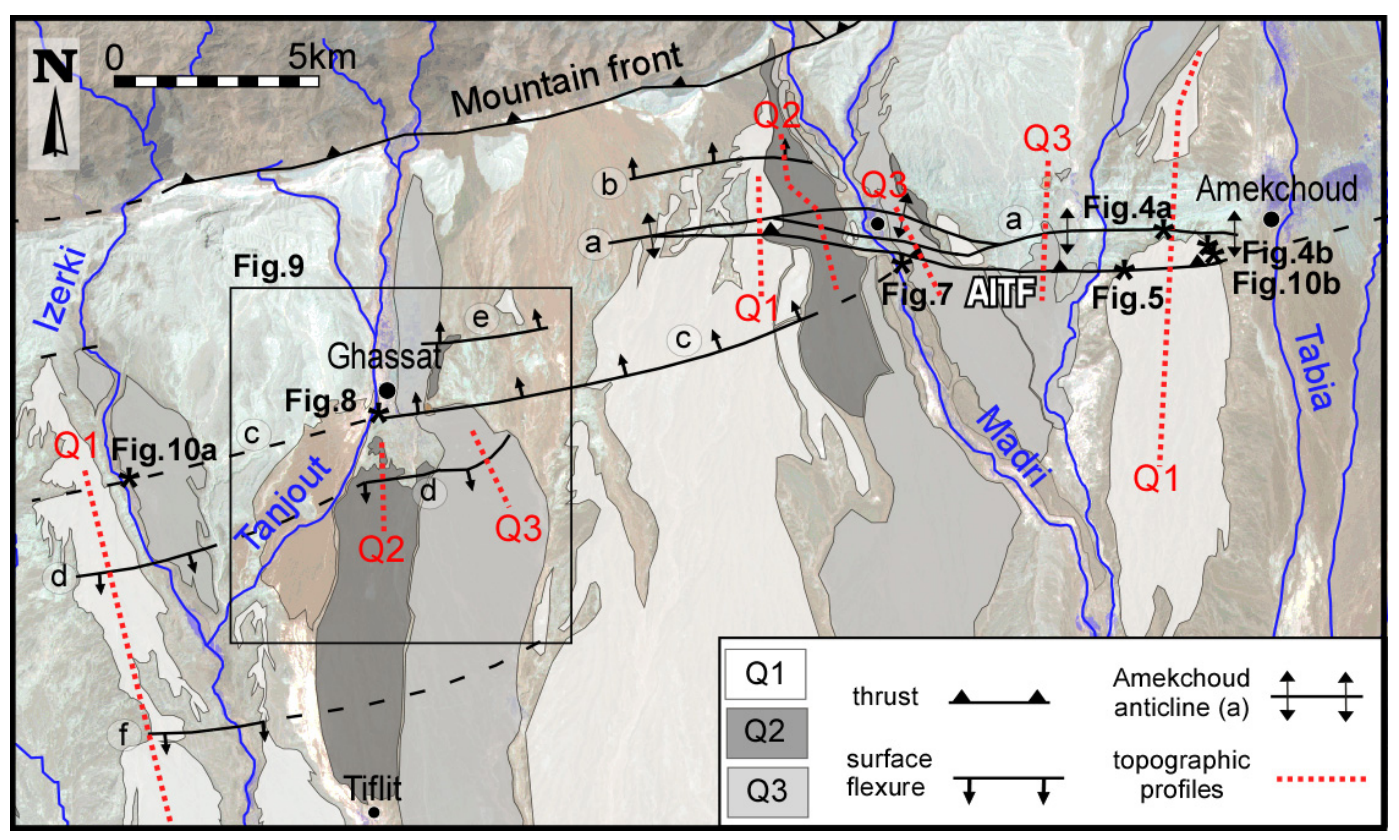

Figure 2. Detailed map of the older Quaternary deposits in the study zone, with the main Quaternary structures (as 'a' to 'e'). The topographic profiles of the Quaternary surfaces (red dashed lines) and the location of field photographs (numbered) are also indicated. AITF: Amekchoud-Imidir thrust fault.

in the entire basin, and the correlation of surfaces can be carried out by comparing their characteristics. We have compared different features between dated and undated surfaces, such as height above the current river, effects of secondary fluvial incision, and stage of carbonate cementation. It needs to be stressed that the absolute height of a terrace with respect to the current river is only an approximate indicator, as the incision rates might be different for each river.

The correlation is straightforward for the Q3 surfaces, because Arboleya et al. [2008] obtained very similar ages in two different valleys, which confirmed coeval terrace abandonment for the different rivers. In contrast, any attempt to correlate terrace Q2 with other surfaces in the basin is speculative. Finally, the dated Q1 fan surface has been correlated to other deposits in different valleys through comparisons of the stage of carbonate cementation, the degree of superimposed rill incision, and the elevation of the surface.

\section{Morphotectonic analysis and structural uplift}

We focused our structural analysis on the frontal-most thrust faults of the SAF in the north-western Ouarzazate Basin (Figure 2). The tectonic structures in the Ouarzazate Basin are broadly E-W oriented thrusts and fault-related folds (anticlines and monoclines). We mapped four transects across the main structures (Figure 1c, boxes 1-4) to investigate the variations in deformational style and shortening. Cross-sections were drawn along N-S streams cutting the tectonic structures orthogonally and providing the best exposures. Information from existing seismic reflection profiles helped us to resolve the deep geometry of some of the structures. Faults and folds are evident in the Tertiary bedrock and in the older Quaternary deposits (Q3 and older); however, they are difficult to trace in a continuous way, because of the covering by the most recent colluvial and streambed sediments. Some of the structures show strong lateral variations and can only be characterized in isolated outcrops. Thus, the most effective way to unravel the recent structural evolution is by topographic analysis of Quaternary surfaces used as tectonic markers.

We divided the study region into four areas from $\mathrm{E}$ to $\mathrm{W}$, named according to the closest main river (Tabia, Madri, Tanjout and Izerki; Figure 1c) and with specific kinds of deformation.

A structural uplift of a Quaternary surface is here defined as the deviation or offset from its regional gradient that is produced by a fault or fold. The uplift was measured using the DEM generated from the Shuttle Radar Topographic Missions (SRTM90). Although their precision can be argued for short transects, SRTM90 data allow the slope of planar geomorphic surfaces to be averaged (for slope values less than $10^{\circ}$ ) with negligible error [e.g., Gorokhovich and Voustianiouk 2006]. However, problems do arise when narrow ridges are measured; in this case, the elevation values obtained must be considered as minimum estimates, because the real values are influenced by the lower elevations at both sides of the ridge. We compared the results obtained from SRTM90 with field methods, such as use of high-precision altimeters, laser levels, and the conventional global positioning system (GPS). When recording the offset of a planar surface (e.g., Izerki's case in Figure 3d), the difference between the values obtained from the DEM and field methods was less than $10 \%$, but when the measure was undertaken at a narrow anticline crest (e.g., for Tabia in Figure 3a), the difference increased by up to $25 \%$. Thus, we concluded that the DEM SRTM90 allows cor- 

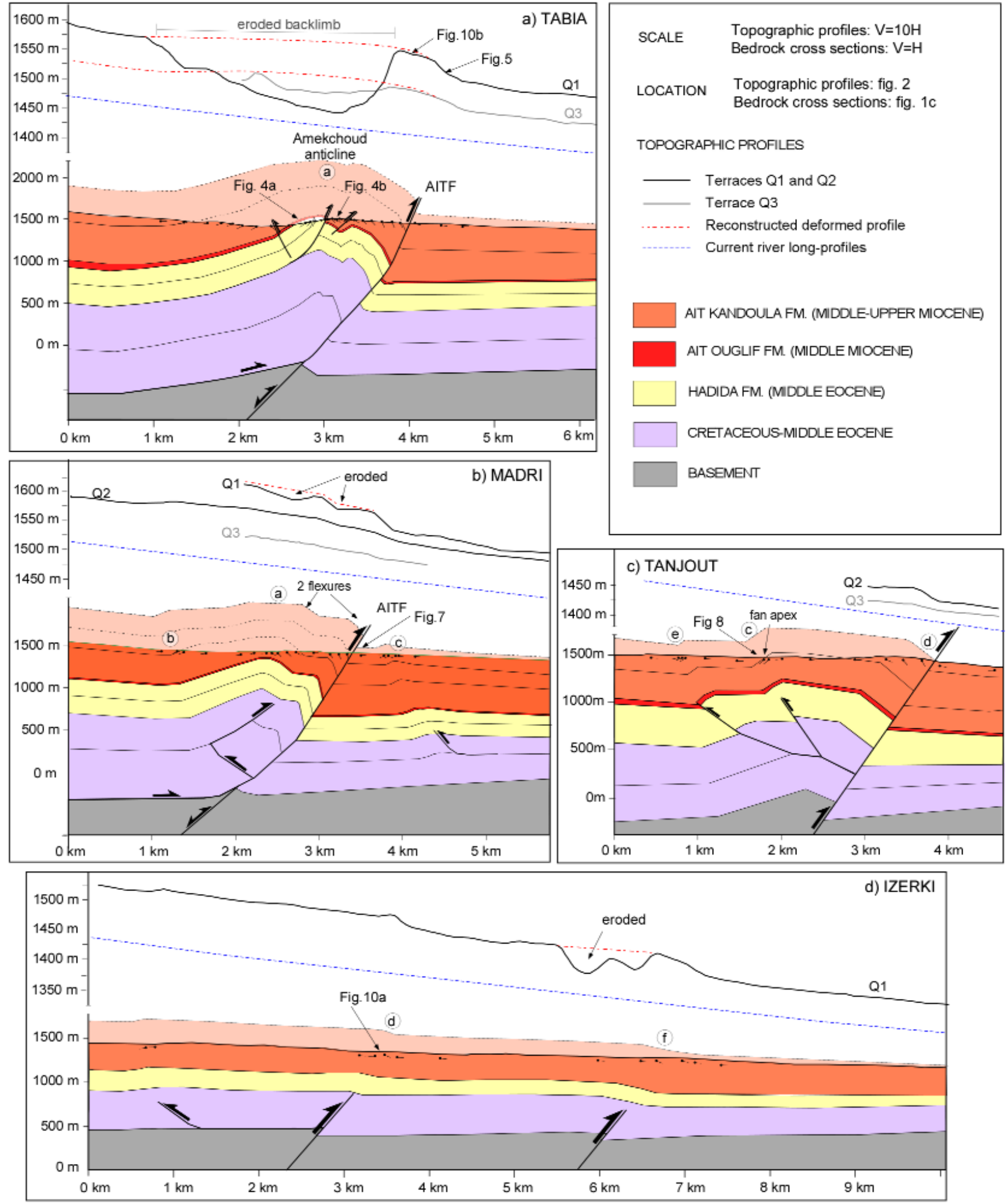

Figure 3. Topographic profiles of Quaternary terraces and geologic cross-sections of the northern Ouarzazate Basin. The topographic profiles were constructed from DEM SRTM90, and the geological cross-sections were based on field data and seismic reflection profiles. The location of topographic profiles is as indicated in Figure 2. The locations of the geological profiles are slightly offset from the Quaternary topographic profiles for the sake of bedrock exposure, and are shown in Figure 1c. Circled letters indicate the tectonic structures labeled in Figure 2 and described in the text.

rect offset values to be obtained for kilometer-scale planar surfaces, but it is not a good tool to obtain reliable elevations or slope values when the relief or slope change is concentrated within a narrow zone. In these cases, we relied on the methods of altimetry, laser levels and conventional GPS. Another advantage of using DEM is the ability to construct many topographic profiles of each deformed zone, which reduces the error associated with a single transect, and removes the effects of secondary fluvial incision. We also compared the SRTM90 DEM with the ASTER30 DEM, with the latter 


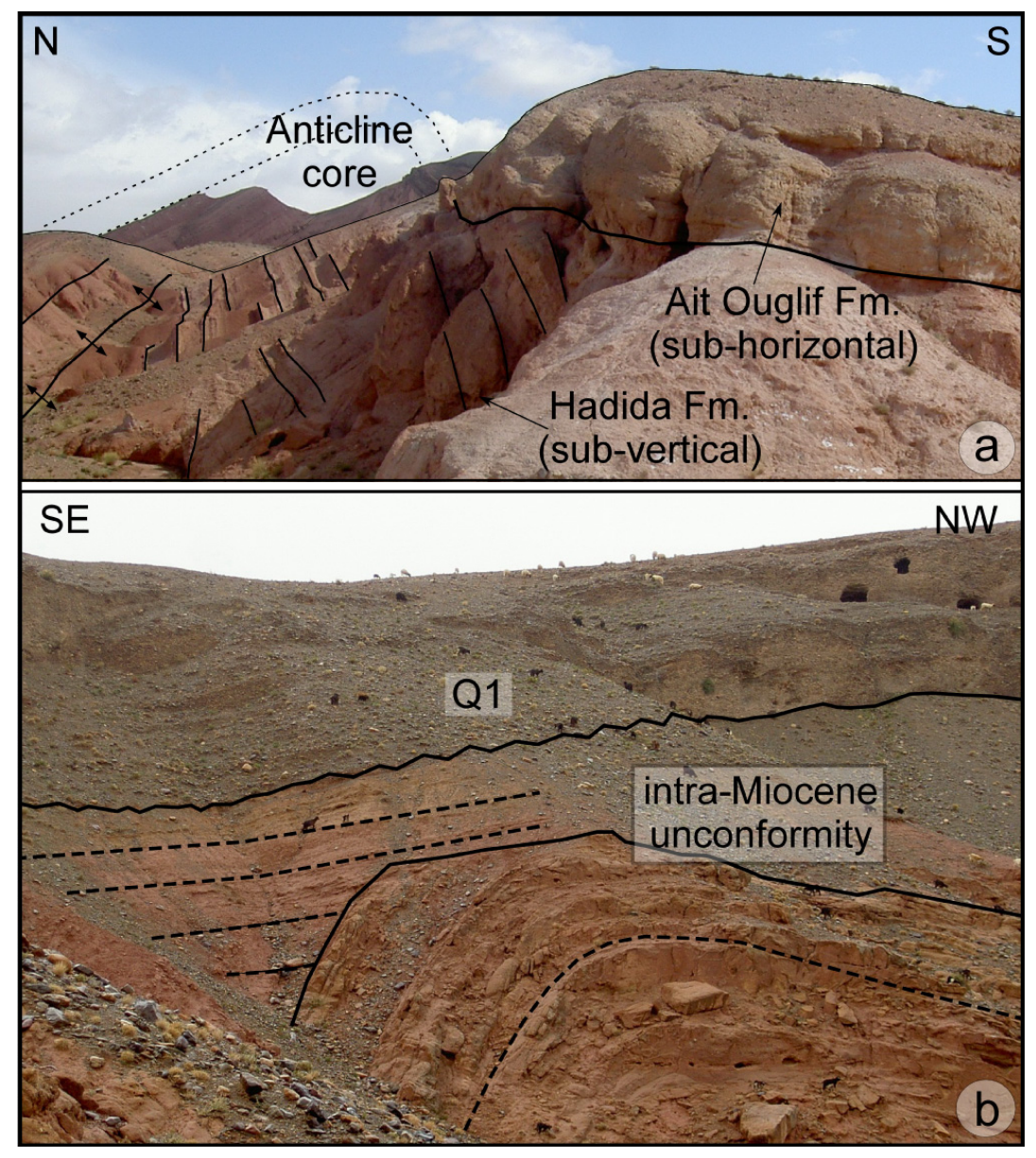

Figure 4. (a) Photograph of a local unconformity between the Hadida and the Ait Ouglif formations in the core of the Amekchoud anticline in the Tabia area, looking from the west. The field of view is ca. $40 \mathrm{~m}$. (b) Minor unconformity within the Miocene red beds of the Ait Kandoula formation in the core of the Amekchoud anticline in the Tabia area. The field of view is ca. $100 \mathrm{~m}$. See Figures 2 and 3 for location.

yielding noisier and less accurate results.

Scarps produced by thrust faults on Quaternary deposits are usually degraded and masked by colluvium wedges. Hence, in most cases, we could not measure the slip produced by the major faults directly in the field. Fortunately, well-preserved fan and terrace surfaces, which were originally flat, can be used successfully for this purpose if they are preserved at both sides of a fault. Even in degraded surfaces with considerable roughness, the average surface gradient can be defined despite the irregularities [e.g. Avouac and Peltzer 1993], and offsets of this gradient due to faulting or warping can be readily estimated. We measured the offsets of the terrace surfaces by comparing the current topographic profile with a reconstructed original profile (Figure 3), on the assumption that the original terrace gradient is preserved in the undeformed zones far away from a fault or monocline. Hence, the structural uplift caused by a fault or fold on a Quaternary marker can be obtained by projecting the terrace gradient from the undeformed tracts to the deformed tracts.

\subsection{The Tabia area}

The river Tabia is located in the eastern part of the study region, where the main tectonic structures are the Amekchoud-Imidir thrust fault (AITF) and the Amekchoud anticline
(Figure 2). The AITF can be identified in satellite images, where it strikes $\mathrm{E}$ to $\mathrm{W}$ for at least $15 \mathrm{~km}$, at $7 \mathrm{~km}$ to $8 \mathrm{~km}$ south of the mountain front. Based on field and seismic data, the cross-section of the Amekchoud anticline (Figure 3a) suggests rough fault-propagation fold geometry with a gently dipping backlimb and a steeper forelimb. Nevertheless, the mechanically weak nature of the Hadida formation makes its geometry and kinematics more complex than the basic model of fault-propagation folding [e.g., Suppe and Medwedeff 1990], as the anticline core is disturbed by minor folds and faults.

The Tabia area is also characterized by having the best Tertiary record throughout the basin, which was the subject of a magnetostratigraphic study [Tesón et al. 2010]. The unconformity between the Hadida formation and the Ait Ouglif conglomerate in the anticline core (Figure 4a) postdates an early stage of folding of this long-lived structure. Similarly, intraformational unconformities within the Ait Kandoula formation indicate synsedimentary folding throughout the Miocene (Figure 4b). Seismic profiles reveal that the location of the AITF ramp coincides with a pre-existing normal fault that involves the basement, although the geometry of the fault-related fold (Amekchoud anticline) still suggests that the thrust is a thin-skinned structure soled in a ca. $2 \mathrm{~km}$-deep detachment level, near the basement-cover 


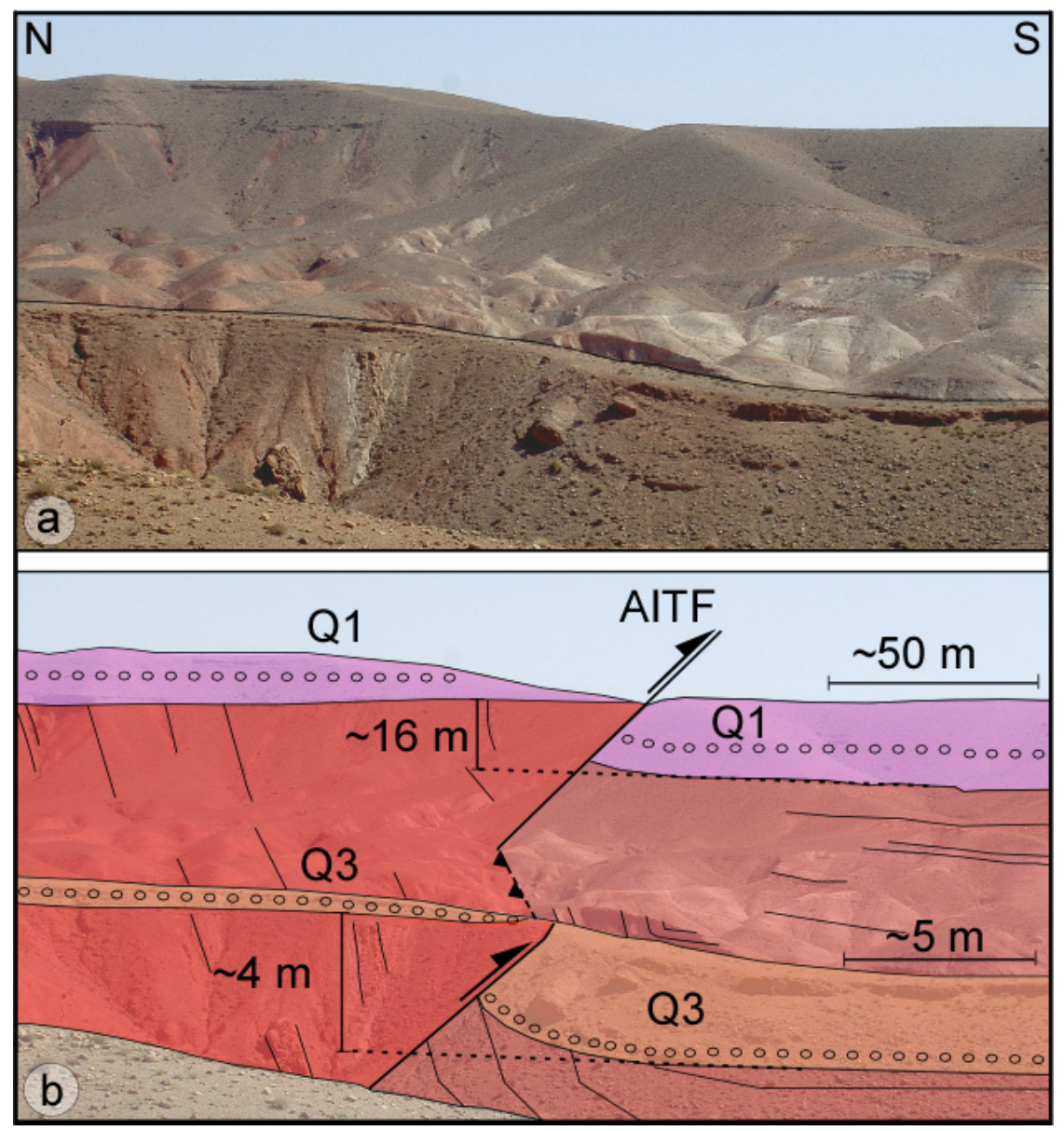

Figure 5. (a) Field image of the Amekchoud-Imidir thrust fault (AITF) in the Tabia area, looking from the west. (b) Interpretation of the image showing how the AITF reaches the surface and cuts the Quaternary deposits (Q1 and Q3). See location in Figures 2 and 3.

interface (Figure 3a). According to Tesón [2009], this detachment is rooted some $10 \mathrm{~km}$ northwards, in a major basement-involved fault in the High Atlas.

The preserved Quaternary deposits appear to be much less folded than the Tertiary beds. Field observations show that the AITF reaches the Quaternary deposits near the surface (Figure 5), although the fault scarp is degraded and masked by colluvial accumulation. Quaternary terraces Q1 and Q3 are susceptible to tectonic analysis in the Tabia area (Figure 3a). Q1 constitutes two exposure areas that are separated by an eroded zone, which largely corresponds to the core of the Amekchoud anticline. However, Q1 is preserved all the way to the south of the anticline crest, where it has been remarkably uplifted (Figure 3a). Our estimate of the local uplift that affects this terrace is $60 \pm 5 \mathrm{~m}$ (Figure 6a). Q3 is a well-cemented deposit that only extends for ca. $7 \mathrm{~km}^{2}$, which covers part of the Amekchoud anticline. Its thickness varies depending on its position with respect to the fault, whereby on average it is $3 \mathrm{~m}$ at the footwall and less than 0.5 $\mathrm{m}$ at the hanging wall (Figure 5). This strath terrace has experienced $24 \pm 3 \mathrm{~m}$ of local uplift at the anticline crest since the abandonment of Q3 (Figure 6a). Based on the abandonment age of the Q1 and Q3 deposits, at the crest of the Amekchoud anticline, we can estimate an average uplift rate of $0.2 \mathrm{~mm} / \mathrm{y}$ to $0.3 \mathrm{~mm} / \mathrm{y}$ during the past $250 \mathrm{ky}$.

\subsection{The Madri area}

The Madri valley contains the best record of fluvial terraces in the entire Ouarzazate Basin [Arboleya et al. 2008]. Terraces Q1, Q2 and Q3 show progressive decrease in the degree of deformation towards the younger and lower surface (Figure 3b). The clearest evidence of Quaternary fault activity is encountered in the eastern incision slopes of the Madri River near Imidir, where the AITF reaches the surface, dipping $60^{\circ} \mathrm{N}$ and bringing the Miocene bedrock onto terrace Q3 (Figure 7). The mapping shows lateral variations of the structures cropping out in the Madri valley. The AITF is affected locally by a slight orientation change (Figure 2), and two north-verging structures appear: the northern one is located $3 \mathrm{~km}$ north of the AITF (Figure 2 and $3 \mathrm{~b}$, as ' $\mathrm{b}$ ') and is related to the evolution of the anticline backlimb; the southern one (Figure 2 and $3 b$, as ' $c$ ') is an asymmetric anticline with gently dipping limbs. This asymmetric anticline can be observed striking WSW to ENE for at least $15 \mathrm{~km}$ westwards, with its maximum development in the Tanjout area. The contact between the Miocene and the Quaternary deposits (Q1) along this north-verging structure is only slightly unconformable, which suggested that this fold formed in recent times. The core of the Amekchoud anticline comprises two south-verging monoclines, both of which have steeply dipping forelimbs $\left(40^{\circ}\right.$ to $80^{\circ}$ ) (Figure $3 \mathrm{~b}$ ). The Amekchoud 


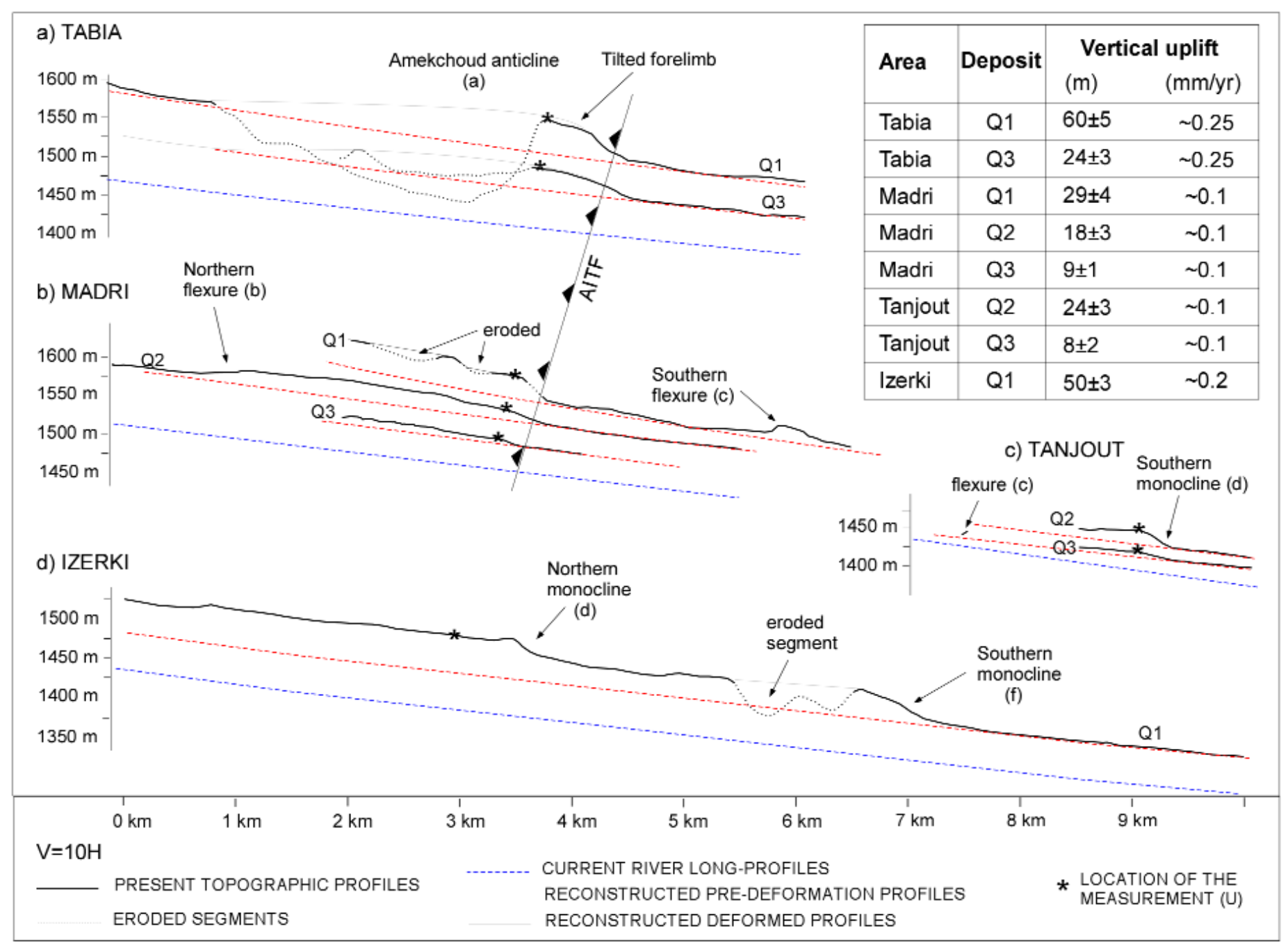

Figure 6. Topographic profiles projected onto lines perpendicular to the structures for the Tabia, Madri, Tanjout and Izerki areas. The profiles are vertically exaggerated 10-fold. Red dashed lines represent the reconstructed pre-deformation profile for each terrace. The table indicates the structural uplift measured $(\mathrm{U})$ for each terrace. The sites where terrace heights were measured are indicated in the profiles.

anticline also affects the unconformable Quaternary terraces, but to a lesser degree than the Miocene.

The AITF fault scarp at terrace Q3 is degraded and masked by a colluvium wedge (Figure 7). To avoid measurement errors, the offset of this terrace was recorded using two methods. The offset obtained by comparing the reconstructed and actual topographic profiles (extracted from the DEM SRTM90) was compared with direct field measurements with tape and laser levels; both methods yielded an offset of $9 \pm 1 \mathrm{~m}$ (Figure 6b). Sébrier et al. [2006] used a DEM constructed from kinematic GPS data, and they reported an elevation difference of $12 \mathrm{~m}$ between two points located north and south of the AITF. However, this estimate is greater than the true vertical uplift related to the fault, because Sébrier et al. [2006] did not take into account the terrace gradient $\left(0.9^{\circ}\right.$ to $\left.1.1^{\circ}\right)$. Q2 and Q1 are also affected by the AITF, which has produced a structural uplift of $18 \pm 3 \mathrm{~m}$ and $29 \pm 4 \mathrm{~m}$, respectively (Figure $6 \mathrm{~b}$ ).

\subsection{The Tanjout area}

The Tanjout area (Figure 1c) shows active tectonics evidence that consists of strongly dipping Quaternary de- posits (Figure 8) and an alluvial fan apex sourced on an intrabasinal fold (Figure 9).

At least three major structures show Quaternary activity here, as they are partially covered by Quaternary deposits. The most prominent is a monocline (Figure 2, as ' $\mathrm{d}$ ') that is related to a north-dipping basement-involved thrust (Figure 3c), which is clearly identified in seismic profiles. The Q2 and Q3 deposits are warped by this structure, thus appearing much less folded than the Tertiary beds. Northwards, two north-verging flexures (Figure 2, as ' $c$ ' and 'e') are related to shallower blind back-thrusts (Figure 3c). These structures affect the Tertiary and Quaternary deposits to a similar degree, attesting to their recent development. The fault-related monocline ' $c$ ' locally tilts by $39^{\circ}$ a Quaternary deposit of unknown age (possibly Q2; Figure 8 ), and sources an alluvial fan within the basin. This area recorded an earthquake in 1991 at a depth of $10 \mathrm{~km}$, which is listed in the online bulletin of the International Seismological Centre. The structural uplift related to the southernmost monocline ' $\mathrm{d}$ ' is recorded by Q2 and Q3, as $23 \pm 3$ $\mathrm{m}$ and $8 \pm 1 \mathrm{~m}$ respectively. These values are comparable to 


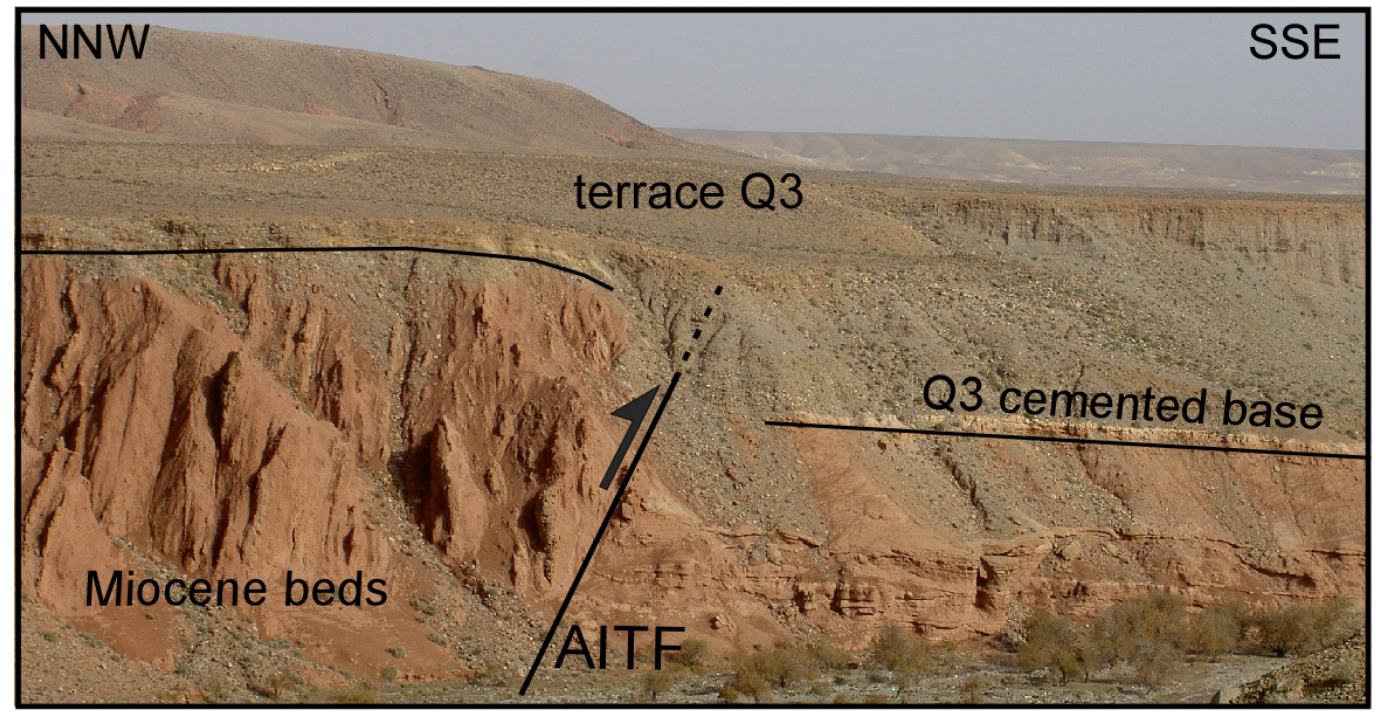

Figure 7. Interpreted image of the eastern slope of the Madri valley where the AITF offsets Q3. The field of view is $400 \mathrm{~m}$ (see location in Figure 2).

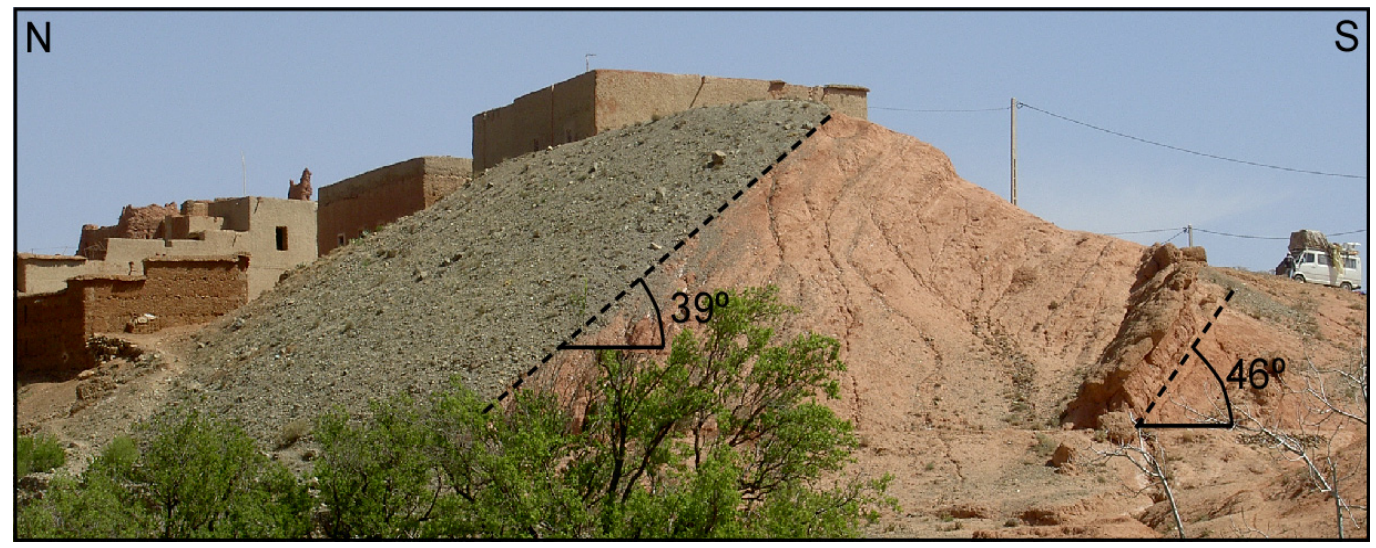

Figure 8. Example of a strongly warped Quaternary deposit (probably Q2), which is almost paraconformant with the Miocene bedrock, at the northverging flexure ' $c$ ' in the Tanjout area. The field of view is $20 \mathrm{~m}$. See location in Figure 2 and 3.

those produced by the AITF in the Madri area. The recent deposits of the Ghassat alluvial fan (post-Q3) do not show any detectable deformation.

\subsection{The Izerki area}

The Izerki area (Figure 1c) is the least deformed transect, and contains only two basement-involved blind thrust faults of small displacement, which change to gentle monoclines near the surface (Figure $3 \mathrm{~d}$ ). The monoclines (Figure 2, as ' $\mathrm{d}$ ' and ' $\mathrm{f}$ ') deform alike the Tertiary and Quaternary deposits. The seismic imagery and the geometry of the monocline folds (narrow forelimbs and long, subhorizontal backlimbs) suggest deep-rooted faulting. The northern structure is the westward continuation of the south-verging basement-involved fault that was described in the Tanjout area (Figure 2, as 'd'), but is less developed (structural uplift of $15 \mathrm{~m}$ since Q1 abandonment). The southern fold (Figure 2, as ' $\mathrm{f}$ ') also shows a constant-elevation backlimb and forelimb (ca. $250 \mathrm{~m}$ long), which dips $5^{\circ}$ to $20^{\circ}$. This fold is easily identified on satellite images, and produces $35 \mathrm{~m}$ of Q1 vertical uplift. Q1 forms here a well- preserved continuous terrace with a cumulative uplift that is produced by both flexures, of ca. $50 \mathrm{~m}$ (Figure $6 \mathrm{~d}$ ) since $250 \mathrm{Ky}$ to $278 \mathrm{Ky}$. The coeval activity of both structures has thus produced an uplift rate of $0.19 \pm 0.01 \mathrm{~mm} / \mathrm{y}$ in the northern third of the basin.

\section{Analysis of the deformation rates}

The southern margin of the High Atlas mountain belt concentrates most of the tectonic shortening acquired through the Cenozoic Atlas orogeny [Beauchamp et al. 1999, Bennami et al. 2001, Teixell et al. 2003, Tesón 2009], and possibly represents the locus of the most active deformation in recent times [Sébrier et al. 2006]. Bedding and fault attitudes in the Tertiary bedrock were used to construct balanced cross-sections (Figure 3), and when combined with the magnetostratigraphic dating [Tesón et al. 2010], these constrain long-term shortening rates since the late Cenozoic. We compared these long-term shortening rates with the minimum shortening rates estimated for the last ca. $250 \mathrm{ky}$. We constrained the recent fault slip-rates for the most active structure in the Ouarzazate Basin. Previous 


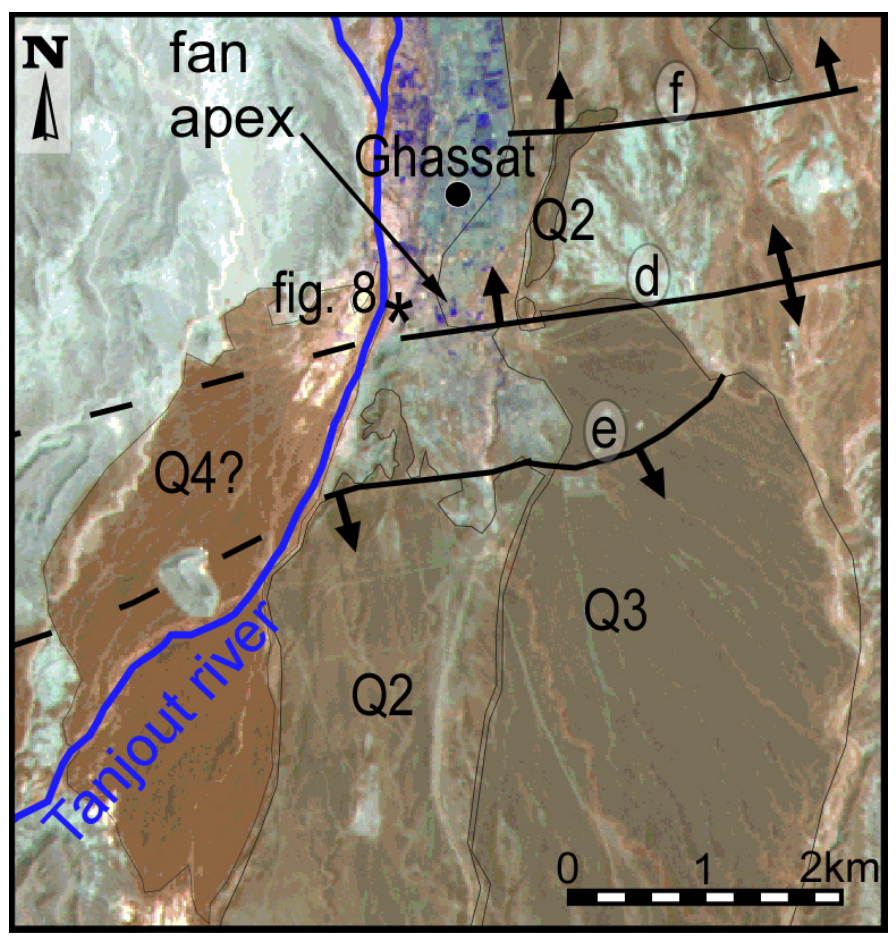

Figure 9. Map of the Quaternary deposits and surface flexures in the Tanjout area, on an ASTER image extract. South of Ghassat, an alluvial fan is sourced on the structure ' $c$ '.

approximations to the active tectonic rates in the Ouarzazate Basin were based on speculative age estimates for the Quaternary deposits.

\subsection{Long-term shortening rates}

The cross-sections in Figure 3 allow the estimation of the tectonic shortening experienced by the Miocene formations, by line-length restoration. The maximum N-S shortening corresponds to the Tabia section $(500-600 \mathrm{~m})$, while the minimum values correspond to the Izerki section $(<50 \mathrm{~m})$. Therefore, the finite deformation accumulated by the Tertiary beds decreases from E-W within the basin, following the general trend described for the SAF [e.g., Tesón 2009].

The Tabia valley is where angular and progressive unconformities within the Tertiary succession provide information on the timing of deformation, and so it is the best place to document the long-term shortening rates of the AITF fault and related folds. The unconformable contact between the Hadida Fm. and the overlying Ait Ouglif conglomerate in the core of the Amekchoud anticline shows that gentle folding started before 14 my ago. A progressive unconformity of the Ait Kandoula strata in the southern limb of the anticline demonstrates continued folding, at least during the rest of the Miocene, punctuated by minor unconformities near the anticline core (Figure $4 \mathrm{~b}$ ). The accurate balanced cross-section in Figure 3a yields $500 \mathrm{~m}$ to 600 $\mathrm{m}$ of shortening for the 14-my-old Ait Ouglif marker bed, which indicates an average shortening rate of $0.04 \pm 0.01$ $\mathrm{mm} / \mathrm{y}$ for the AITF since the Middle Miocene. A previous assessment by Sébrier et al. [2006] inferred the shortening rate for the AITF as between $0.04 \mathrm{~mm} / \mathrm{y}$ and $0.1 \mathrm{~mm} / \mathrm{y}$, although they assumed a Pliocene age for the beginning of the AITF activity, and estimated only $200 \mathrm{~m}$ of total shortening.

\subsection{Recent deformation rates}

The offsets recorded by the stepped terraces in the Madri area allow the estimation of the slip rates for the AITF across different time-spans of the late Pleistocene. The vertical offset produced by this $60^{\circ}$-dipping fault, combined with the terrace chronology by Arboleya et al. [2008], allow the calculation of a slip rate of ca. $0.1 \mathrm{~mm} / \mathrm{y}$ over the last ca. 100 ky (since the abandonment of Q3).

We also estimated the shortening accommodated in the Tabia area by line-length restoration of terrace Q1. The striae orientations measured in a fault plane of a minor conjugate fault set in the Tabia transect (Figure 10) suggested that the fault displacement is dip-slip and broadly N-S, perpendicular to the strike of the main structures. Hence, we assumed pure reverse faulting without a lateral component. A simple reconstruction for the eroded segment (linear joining of the preserved segments) of the Q1 profile provides an estimation of the minimum shortening experienced by this terrace. The resulting shortening rate has been ca. $0.1 \mathrm{~mm} / \mathrm{y}$ since the abandonment of Q1. This value is certainly a minimum value, as we have used a very conservative reconstruction of the anticline profile that does not take into account the shortening accommodated by minor faults. We have probably neglected the presence of most of these faults, even in the preserved forelimb, because their effects over a badly sorted terrace deposit can be imperceptible. As they are easily eroded or covered by colluviums, the poor degree of preservation of the fault planes, as well as the scarce presence of layers acting as deformation markers, can mask the displacement produced by these small-slip faults.

\section{Discussion}

Most studies that have calculated slip rates of thrust faults at Quaternary time-scales from the deformation of terrace markers were carried out in settings with high tectonic convergence rates, such as the Tien Shan [Thompson et al. 2002], the Gansu Province in NW China [Gold et al. 2006], and the Mackenzie Basin in New Zealand [Amos et al. 2007]. These rates are often an order of magnitude greater than the rates deduced for the Ouarzazate Basin. While studies in fast tectonic areas usually record deformation rates on time-scales between $1 \mathrm{ky}$ and $10 \mathrm{ky}$, we have analyzed the deformation for terraces older than $100 \mathrm{ky}$. Longlived structures, such as the AITF and the Amekchoud anticline, are usually not covered by terraces in fast tectonic settings. The presence of four dated deposits with ages $<250$ ky provides a dataset on the deformation rates, enabling the discussion of an apparent increase in the shortening rates during the late Pleistocene. 


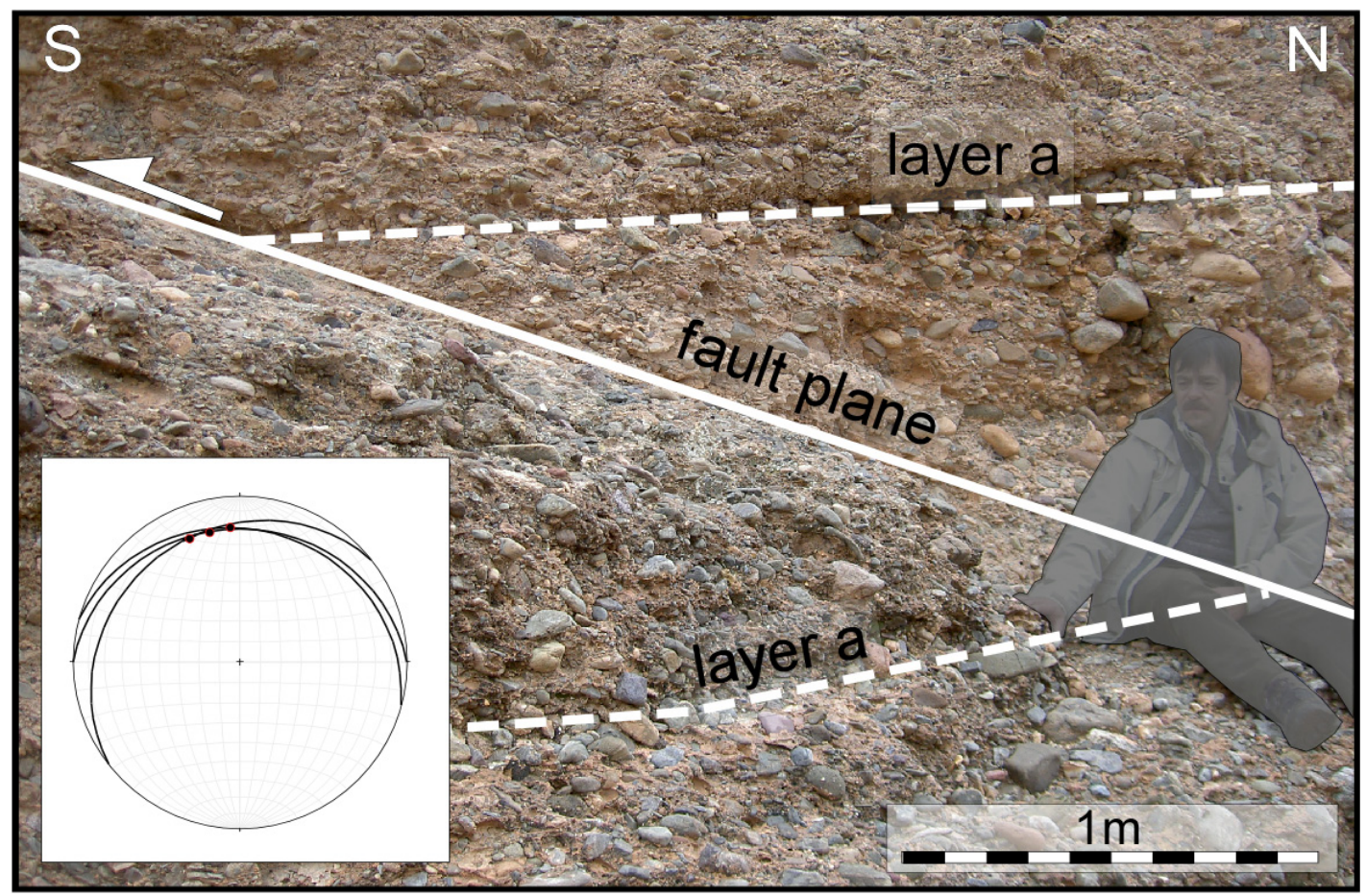

Figure 10. Interpretation of a field photograph showing a minor fault affecting Q1 at the Tabia area, looking from the east. See location in Figures 2 and 3. This fault, which dips $21^{\circ}$ to the north and has a displacement of $2.5 \mathrm{~m}$, is only recognizable at the well-cemented base of Q1. The fault plane is exhumed and exposes the striae plotted in the stereogram.

\subsection{Are recent deformation rates higher than the long-term ones?}

The results of the present study indicate a difference between the long-term shortening rates calculated since the Miocene, and the recent shortening, uplift and fault-slip rates calculated for the late Quaternary. Recent increments in the shortening rates is evident for the Tabia area, where we estimated a minimum value of ca. $0.1 \mathrm{~mm} / \mathrm{y}$ over the past ca. $250 \mathrm{ky}$. These rates are particularly high in relation to the average long-term shortening rates since the Middle Miocene $(0.04 \pm 0.01 \mathrm{~mm} / \mathrm{y})$. Other criteria also favor the increment of deformation rates towards the present; for example, the vertical uplift measured at the crest of the Amekchoud anticline is $24 \pm 3 \mathrm{~m}$ for Q3 (96-102 ky) and $60 \pm 5 \mathrm{~m}$ for Q1 (250$278 \mathrm{ky}$ ), which imply structural uplift rates as fast as ca. 0.25 $\mathrm{mm} / \mathrm{y}$. Assuming these rates since the deformation onset (14 My ago), the resulting total uplift would be at least three times higher than that observed (Figure 3a). It might be argued that the total deformation rates calculated since the Miocene are indeed long-term ones, as the sedimentary record does not provide resolution to ascertain whether the deformation was relatively continuous in time or heterogeneously distributed (with periods of fast movement separated by periods of relative quiescence). However, we believe that the maintenance of faster rates during the past $250 \mathrm{ky}$ is significant, and is supported by the recent development of deformation structures. These recently created structures have been recognized in the Izerki area and in the central part of the basin (north-verging flexure ' $c$ '), where the boundary between the Tertiary red beds and the Quaternary gravels is almost paraconformable (e.g., Figure 8).
It is worth noting that the Miocene growth of the AITF and the Amekchoud anticline occurred during net deposition of the Ait Kandoula formation in the Ouarzazate Basin, which most likely overlapped the growing fold. A removal of sediments has been documented since the aperture of the formerly endorheic Ouarzazate Basin in the Pliocene or early Pleistocene [Arboleya et al. 2008]. If we assume that the increase in shortening rates recorded by the Quaternary markers is tectonically significant, then we can tentatively underscore the temporal coincidence of the increased rates with the erosional unloading of the Ouarzazate Basin. A clear link between the slip history of active faults and mass fluctuations on the Earth surface was recently established, by a comparison of predictions from numerical models with geological and paleoseismological data [Hetzel \& Hampel 2005, Hampel et al. 2007, Turpeinen et al. 2008, Maniatis et al. 2009, Fernández-Ibáñez et al. 2010, Hampel et al. 2010]. Such mass fluctuations include basin denudation and variations in the volumes of ice-caps or lakes that occurred at time-scales of $10 \mathrm{ky}$ to $100 \mathrm{ky}$. Models show that loading and flexure of the lithosphere decreases slip, whereas unloading and rebound accelerates slip [Hampel et al. 2010]. We speculate that such a correlation could also apply to the Ouarzazate Basin, although further studies are needed to test this hypothesis.

\subsection{Considering a potential large earthquake along the AITF}

The AITF offsets vertically the cemented Q3 base by 13 $\pm 1 \mathrm{~m}$, although it only displaces the terrace surface by $9 \pm 1$ $\mathrm{m}$, where the fault scarp is degraded and covered by colluvium. This difference in offset between the base and top in- 
dicates that part of the deformation occurred during the deposition of the fluvial terrace gravels. This interpretation is reinforced by the differences in the terrace thicknesses at both sides of the fault. A question that arises is how separated in time are tectonic pulses along the fault. Although the average dip-slip rate measured at the AITF has been ca. $0.1 \mathrm{~mm} / \mathrm{y}$ since the abandonment of the Q3 surface (ca. 100 ky), the younger terrace Q4 (early Holocene) is apparently not faulted or warped [Sébrier et al. 2006, Arboleya et al. 2008], which suggests that the AITF has not been active during the last ca. $10 \mathrm{ky}$. These observations can be interpreted in two ways: a) the tectonic activity is finished in this region; or b) another slip increment might suddenly occur after $10 \mathrm{ky}$ of quiescence, to produce an earthquake. Shallow faults along the southern High Atlas front are seismogenic, as shown by the 1960 destructive Mw ca. 6, Agadir earthquake [e.g., Meghraoui et al. 1998, Mridekh et al. 2009]. Considering the estimated fault slip rates $(0.12 \pm 0.03 \mathrm{~mm} / \mathrm{y})$, a quiescence period of ca. $10 \mathrm{ky}$, and a surface rupture length of $17 \mathrm{~km}$, the AITF would be able to produce a Mw ca. 6.5 earthquake, according to the ratios of Slemmons and Depolo [1986] and Wells and Coppersmith [1994]. A 50-cm-thick porous travertine layer appears to be associated with the fault zone in the Tabia area, with an extension of $300 \mathrm{~m}^{2}$ (a rather unique occurrence of this rock type in the Ouarzazate Basin, to our knowledge), and might be related to the emanation of hydrothermal fluids from depth after an earthquake [e.g., Hancock et al. 1999].

\section{Conclusions}

The frontal thrusts of the Atlas orogenic belt penetrate and deform the Ouarzazate foreland basin, which includes Quaternary deposits. These structures have lateral variations and abrupt terminations. Within the western Ouarzazate foreland basin, the folding dynamics suggest that two coeval tectonic styles occurred simultaneously: faults involving the basement in the west, and faults related to a shallow detachment level (at the base of post-Paleozoic cover) in the east. Deep seismic reflection images and topography features attest to the different tectonic styles. In the western Ouarzazate basin, the 250 ky to $278 \mathrm{ky}$ Q1 deposits of the Izerki valley lie above the Tertiary bedrock with an almost concordant geometry, which indicates that most of the observed deformation has occurred since the Upper Pleistocene. The AITF started its activity at least 14 million years ago, and it has also been active during the last ca. $250 \mathrm{ky}$. The comparison of the estimated short-term (ca. $0.1 \mathrm{~mm} / \mathrm{y}$ during the last ca. $250 \mathrm{ky}$ ) with long-term shortening rates (ca. $0.04 \mathrm{~mm} / \mathrm{y}$ since the Middle Miocene) suggest that the tectonic activity of the SAF structures is not continuous in time, whereby it was greater during the Quaternary. We tentatively relate this increment in the AITF activity to sediment unloading of the Ouarzazate Basin since it became externally drained.

\section{Data and sharing resources}

The earthquake data used in this study were from the database of the International Seismological Centre (ISC), and can be requested at this address: http:/ / www.isc.ac.uk/ search/bulletin/index.html.

Acknowledgements. This work was supported by the Spanish Projects CGL2006-07226, CGL2010-15416, Consolider-Ingenio 2010 CDS2006-00041 (TOPOIBERIA), and CGL2007-66431-CO2-01 (TOPOMED). We thank A. Azor and P. Santanach for revisions that helped us to improve this manuscript.

\section{References}

Amos, C.B., D.W. Burbank, D.C. Nobes and S.A.L. Read (2007). Geomorphic constraints on listric thrust faulting: implications for active deformation in the Mackenzie Basin, South Island, New Zealand, J. Geophys. Res., 112, B03S11; doi:10.1029/2006jb004291.

Arboleya, M.L., A. Teixell, M. Charroud and M. Julivert (2004). A structural transect through the High and Middle Atlas of Morocco, J. African Earth Sci., 39, 319-327.

Arboleya, M.L., J. Babault, L.A. Owen, A. Teixell and R.C. Finkel (2008). Timing and nature of Quaternary fluvial incision in the Ouarzazate foreland basin, Morocco, J. Geol. Soc., 165, 1059-1073.

Avouac, J.P., and G. Peltzer (1993). Active tectonics in southern Xinjiang, China: analysis of terrace riser and normal fault scarp degradation along the Hotan-Qira Fault System, J. Geophys. Res., 98, 21773-21807.

Ayarza, P., F. Alvarez-Lobato, A. Teixell, M.L. Arboleya, E. Teson, M. Julivert and M. Charroud (2005). Crustal structure under the central High Atlas Mountains (Morocco) from geological and gravity data, Tectonophysics, 400, 67-84.

Babault, J., A. Teixell, M.L. Arboleya and M. Charroud (2008). A Late Cenozoic age for long-wavelength surface uplift of the Atlas Mountains of Morocco, Terra Nova, 20, 102-107.

Beauchamp, W., R.W. Allmendinger, M. Barazangi, A. Demnati, M. El Alji and M. Dahmani (1999). Inversion tectonics and the evolution of the High Atlas Mountains, Morocco, based on a geological-geophysical transect, Tectonics, 18, 163-184.

Benammi, M., E. Arbi Toto and S. Chakiri (2001). Les chevauchements frontaux du Haut Atlas central marocain : styles structuraux et taux de raccourcissement différentiel entre les versants nord et sud. On the differential structural styles and rates of shortening on the northern and southern bordering thrusts of the Moroccan Central Atlas, Comptes Rendus de l'Académie des Sciences - Series IIA - Earth and Planetary Science, 333, 241-247.

Couvreur, G. (1973). Etagement de formes et néotectonique sur le versant sud du Haut Atlas, Revue de Géomorphologie Dynamique, 22, 109-124. 
El Harfi, A., J. Lang, J. Salomon and E.H. Chellai (2001). Cenozoic sedimentary dynamics of the Ouarzazate foreland basin (Central High Atlas Mountains, Morocco), Intl. J. Earth Sci., 90, 393-411.

Errarhaoui, K. (1997). Structure du Haut Atlas: plis et chevauchements du socle et de couverture (interprétations des données géophysiques et géologiques), Thèse Doctorale, Univ. Paris-Sud, Orsay, 1-378.

Fernández-Ibáñez, F., J.V. Pérez-Peña, A. Azor, J.I. Soto and J.M. Azañón (2010). Normal faulting driven by denudational isostatic rebound, Geology, 38, 643-646.

Fraissinet, C., E.M. Zouine, J.L. Morel, A. Poisson, J. Andrieux and A. Faure-Muret (1988). Strutural evolution of the southern and northern central High Atlas in Paleogene and Miopliocene times, in The Atlas System of Morocco, V. Jacobshagen (Editor), Springer-Verlag, New York, 272-291.

Frizon de Lamotte, D., B. Saint Bezar, R. Bracène and E. Mercier (2000). The two main steps of the Atlas building and geodynamics of the western Mediterranean, Tectonics, 19, 740-761.

Frizon de Lamotte, D., P. Leturmy, Y. Missenard, S. Khomsi, G. Ruiz, O. Saddiqi, F. Guillocheau and A. Michard (2009). Mesozoic and Cenozoic vertical movements in the Atlas system (Algeria, Morocco, Tunisia): An overview, Tectonophysics, 475, 9-28.

Fullea, J., M. Fernàndez, H. Zeyen and J. Vergés (2007). A rapid method to map the crustal and lithospheric thickness using elevation, geoid anomaly and thermal analysis. Application to the Gibraltar Arc System, Atlas Mountains and adjacent zones, Tectonophysics, 430, 97-117.

Gold, R.D., E. Cowgill, X.F. Wang and X.H. Chen (2006). Application of trishear fault-propagation folding to active reverse faults: examples from the Dalong Fault, Gansu Province, NW China, J. Struct. Geol., 28, 200-219.

Görler, K., F.F. Helmdach, P. Gaemers, K. Heißig, W. Hinsch, K. Mädler, W. Schwarzhans and M. Zucht (1988). The uplift of the central High Atlas as deduced from Neogene continental sediments of the Ouarzazate province, Morocco, in The Atlas System of Morocco, V. Jacobshagen (Editor), Springer-Verlag, New York, 361-404.

Gorokhovich, Y., and A. Voustianiouk (2006). Accuracy assessment of the processed SRTM-based elevation data by CGIAR using field data from USA and Thailand and its relation to the terrain characteristics, Remote Sens. Environ., 104, 409-415.

Guimerà, J., M.L. Arboleya and A. Teixell (2011). Structural control on present-day topography of a basement massif: the central and eastern Anti-Atlas (Morocco), Geologica Acta, 9, 55-65.

Hampel, A., R. Hetzel and A.L. Densmore (2007). Postglacial slip-rate increase on the Teton normal fault, northern Basin and Range Province, caused by melting of the Yel- lowstone ice cap and deglaciation of the Teton Range? Geology, 35, 1107-1110.

Hampel, A., R. Hetzel and G. Maniatis (2010). Response of faults to climate-driven changes in ice and water volumes on Earth's surface, Phil. Trans. Roy. Soc., 368, 2501-2517.

Hancock, P.L., R.M. L. Chalmers, E. Altunel and Z. Çakir $(1999)$. Travitonics: using travertines in active fault studies, J. Struct. Geol., 21, 903-916.

Hetzel, R., and A. Hampel (2005). Slip rate variations on normal faults during glacial-interglacial changes in surface loads, Nature, 435, 81-84.

Jacobshagen, V.H. (1988). Geodynamic evolution of the Atlas system, Morocco; an introduction, In: V.H. Jacobshagen (ed.), The Atlas system of Morocco, Springer-Verlag, Berlin-Heidelberg-New York, 3-9.

Lavé, J., and J.P. Avouac (2000). Active folding of fluvial terraces across the Siwaliks Hills, Himalayas of central Nepal, J. Geophys. Res., 105, 5735-5770.

Laville, E., J.L. Lesage and M. Séguret (1977). Géometrie, cinématique (dynamique) de la tectonique atlasique sur le versant sud du Haut Atlas marocain. Aperçu sur les tectoniques hercyniennes et tardi-hercyniennes, Bulletin de la Société Géologique de France, 19, 527-539.

Laville, E., and A. Piqué (1992). Jurassic penetrative deformation and Cenozoic uplift in the central High Atlas (Morocco); a tectonic model; structural and orogenic inversions, Geologische Rundschau, 81, 157-170.

Maniatis, G., D. Kurfeß, A. Hampel and O. Heidbach (2009). Slip acceleration on normal faults due to erosion and sedimentation -- results from a new three-dimensional numerical model coupling tectonics and landscape evolution, Earth Planet. Sci. Lett., 284, 570-582.

Mattauer, M., P. Tapponier and F. Proust (1977). Sur les mécanismes de formation des chaines intracontinentales. L'exemple des chaines atlasiques du Maroc, Bulletin de la Société Géologique de France, 7, 521-536.

Meghraoui, M., F. Outtani, A. Choukri and D. Frizon de Lamotte (1998). Coastal tectonics across the South Atlas thrust front and the Agadir active zone, Morocco, Coastal Tectonics, Geol. Soc. Lond. Special Publication, 146, 239253.

Missenard, Y., H. Zeyen, D. Frizon de Lamotte, P. Leturmy, C. Petit, M. Sébrier and O. Saddiqi (2006). Crustal versus asthenospheric origin of relief of the Atlas Mountains of Morocco, J. Geophys. Res., 111, B03401; doi:10.1029/2005 JB003708.

Morel, J.L., E.M. Zouine, J. Andrieux and A. Faure-Muret (2000). Deformations neogenes et quaternaires de la bordure nord haut atlasique (Maroc): role du socle et consequences structurales: Neogene and Quaternary deformation of the northern High Atlas border [Morocco]: role of the basement and structural consequences, J. African Earth Sci., 30, 119-131. 
Mridekh, A., F. Medina, N. Mhammdi, F. Samaka and R. Boautmani (2009). Structure of the Kasbah fold zone (Agadir bay, Morocco). Implications on the chronology of the recent tectonics of the western High Atlas and on the seismic hazard of the Agadir area, Estudios Geológicos, 65, 121-132.

Ramdani, F. (1998). Geodynamic implications of intermediate-depth earthquakes and volcanism in the intraplate Atlas Mountains (Morocco), Physics Earth Planet. Int., 108, 245-260.

Seber, D., M. Barazangi, B.A. Tadili, M. Ramdani, A. Ibenbrahim and D. Ben Sari (1996). Three-dimensional upper mantle structure beneath intraplate Atlas and interplate Rif mountains of Morocco, J. Geophys. Res., 101, 31253138.

Sébrier, M., L. Siame, E.M. Zouine, T. Winter, Y. Missenard and P. Leturmy (2006). Active tectonics in the Moroccan High Atlas, Comptes Rendus Geosciences, 338, 65-79.

Slemmons, D.B., and C.M. Depolo (1986). Evaluation of active faulting and associated hazards, In: Active Tectonics, R.E. Wallace (Editor), National Academy Press, Washington, 45-62.

Stäblein, G. (1988). Geomorphological aspects of the Quaternary evolution of the Ourzazate Basin, southern Morocco, in The Atlas System of Morocco, V. Jacobshagen (Editor), Springer-Verlag, New York, 433-444.

Suppe, J., and D.A. Medwedeff (1990). Geometry and kinematics of fault-propagation folding, Eclogae Geol. Helv., 83, 409-454.

Teixell, A., M.L. Arboleya, M. Julivert and M. Charroud (2003). Tectonic shortening and topography in the central High Atlas (Morocco), Tectonics, 22, 1051; doi: $10.1029 / 2002$ TC001460.

Teixell, A., P. Ayarza, H. Zeyen, M. Fernàndez and M.L. Arboleya (2005). Effects of mantle upwelling in a compressional setting: the Atlas Mountains of Morocco, Terra Nova, 17, 456-461.

Teixell, A., G. Bertotti, D. Frizon de Lamotte and M. Charroud (2009). The geology of vertical movements of the lithosphere: An overview, Tectonophysics, 475, 1-8.

Tesón, E., and A. Teixell (2008). Sequence of thrusting and syntectonic sedimentation in the eastern Sub-Atlas thrust belt (Dadès and Mgoun valleys, Morocco), Intl. J. Earth Sci., 97, 103-113.

Tesón, E. (2009). Estructura y cronología de la deformación en el borde Sur del Alto Atlas de Marruecos a partir del registro tectono-sedimentario de la cuenca de antepaís de Ouarzazate, Tesis Doctoral, Univ. Autònoma de Barcelona, Spain, 1-221.

Tesón, E., E.L. Pueyo, A. Teixell, A. Barnolas, J. Agustí and M. Furió (2010). Magnetostratigraphy of the Ouarzazate Basin: Implications for the timing of deformation and mountain building in the High Atlas Mountains of Mo- rocco, Geodinamica Acta, 23, 151-165.

Thompson, S.C., R.J. Weldon, C.M. Rubin, K. Abdrakhmatov, P. Molnar and G.W. Berger (2002). Late Quaternary slip rates across the central Tien Shan, Kyrgyzstan, central Asia, J. Geophys. Res., 107, 2203.

Turpeinen, H., A. Hampel, T. Karow and G. Maniatis (2008). Effect of ice sheet growth and melting on the slip evolution of thrust faults, Earth Planet. Sci. Lett., 269 , 230-241.

Wells, D.L., and K.J. Coppersmith (1994). New empirical relationships among magnitude, rupture length, rupture width, rupture area, and surface displacement, Bull. Seismol. Soc. Am., 84, 974-1002.

Zeyen, H., P. Ayarza, M. Fernàndez and A. Rimi (2005). Lithospheric structure under the western African-European plate boundary: A transect across the Atlas Mountains and the Gulf of Cadiz, Tectonics, 24, TC2001; doi:10.1029/2004TC001639.

${ }^{\star}$ Corresponding author: Àlvar Pastor,

Universitat Autònoma de Barcelona, Departament de Geologia, Bellaterra, Barcelona, Spain; email: alvar.pastor@uab.cat.

(C) 2012 by the Istituto Nazionale di Geofisica e Vulcanologia. All rights reserved. 